http://dx.doi.org/10.18778/8088-187-7.19

Marian Mikołajczyk

\title{
Proces przed krzemienieckim sądem miejskim w Leśniowie w 1747 r. Z badań nad praktyką wymiaru sprawiedliwości w miastach przedrozbiorowej Rzeczypospolitej
}

$\mathrm{D}$

otychczasowe badania nad materialnym i procesowym prawem karnym miast dawnej Polski pozwoliły w miarę dobrze poznać nie tylko normatywne podstawy owego prawa i dorobek ówczesnych pisarzy-prawników, ale i praktykę wymiaru sprawiedliwości, chociaż w tym ostatnim wypadku nasza wiedza jest wciąż cząstkowa. Wiemy wprawdzie sporo o prawie i postępowaniu karnym w Gdańsku, Poznaniu, Krakowie i kilku innych miastach Małopolski ${ }^{1}$, nie jesteśmy jednak w stanie stwierdzić, czy ustalenia te można choćby w zarysie odnieść do innych miejscowości i regionów. Wyrywkowe badania ${ }^{2}$ wskazują zreszta,

${ }^{1}$ Zob. zwłaszcza W. Meinecke, Das Strafrecht der Stadt Danzig bis zur Carolina, Marburg 1932; W. Maisel, Poznańskie prawo karne do końca XVI wieku, Poznań 1963; tenże, Prawo karne w statutach miast polskich do końca XVIII wieku, CPH, 1974, t. XXVI, z. 2; tenże, Sądownictwo miasta Poznania do końca XVI wieku, Poznań 1961; A. Meye, Das Strafrecht der Stadt Danzig von der Carolina bis zur Vereinigung Danzigs mit der Preußischen Monarchie (1532-1793), Danzig 1935; M. Mikołajczyk, Proces kryminalny w miastach Małopolski XVI-XVIII wieku, Katowice 2013; tenże, Przestępstwo i kara w prawie miast Polski południowej XVI-XVIII wie$k u$, Katowice 1998. Dodać należy też drobniejsze opracowania, przynajmniej częściowo omawiające prawo niektórych mniejszych miejscowości (np. dwuczęściowy artykuł Zbigniewa Głąba, Zbrodnia i kara - z dziejów przestępczości w małym mieście w XVII wieku (na przykładzie Lutomierska), „Studia z Dziejów Państwa i Prawa Polskiego” 2008, t. XI, cz. I; 2009 , t. XII, cz. II czy też tekst Jacka Sobczaka, Ustrój miasta i organizacja sądownictwa miejskiego Stupcy w XVII i XVIII wieku, [w:] Historia prawa. Historia kultury. Liber memorialis Vitoldo Maisel dedicatus, red. E. Borkowska-Bagieńska, H. Olszewski, Poznań 1994) oraz prace poświęcone wybranym zagadnieniom, np. torturom (por. choćby W. Maisel, Tortury w praktyce sadu kryminalnego miasta Poznania w wieku XVI-XVIII, „Studia i Materiały do Dziejów Wielkopolski i Pomorza" 1979, t. XIII, z. 1; W. Uruszczak, Tortures judiciaires dans l'ancienne Pologne à la lumière du Livore des malfaiteurs du Tribunal criminel de Wiśnicz du XVII siècle, [w:] La torture judiciaire. Approches historiques et juridiques, red. B. Durand, przy współpracy L. Otis-Cour, Lille 2002).

${ }^{2}$ M. Mikołajczyk, Interrogatoria ante publicationem decreti. Uroczyste potwierdzanie zeznań w praktyce sąu miejskiego w Grodzisku Wielkopolskim w I połowie XVIII wieku, [w:] Pro memoria. Księga dla uczczenia pamięci Profesor Krystyny Kamińskiej, red. A. Gaca, Toruń 2013; 
że różnice rzeczywiście istniały, być może nawet dotyczyły podstawowych zasad prawa. Wskazane jest zatem, choćby dla celów porównawczych, kontynuowanie badań nad praktyką sądową w sprawach karnych w miastach (zwłaszcza mniejszych) Wielkopolski, Prus Królewskich, Mazowsza, Rusi Czerwonej, Wołynia, Podola, Wielkiego Księstwa Litewskiego...

W Archiwum Głównym Akt Dawnych w Warszawie przechowywana jest księga spraw kryminalnych królewskiego Krzemieńca z lat 1747$1764^{3}$. Chociaż obejmuje ona zaledwie kilkanaście lat działalności miejskiego sądu, wpisów jest sporo - zarejestrowano w niej bowiem 57 ponumerowanych spraw. Sąd krzemieniecki - podobnie jak inne sądy miejskie - nie ograniczał się do rozpoznawania spraw kryminalnych związanych bezpośrednio z miastem i jego mieszkańcami i rozpatrywał również „kryminały" z okolicznych wsi, a także mniejszych, być może nie posiadających prawa miecza, miast ${ }^{4}$. Jedną z tych spraw, zapisaną jako "Numero 6to" stanowiło $\mathrm{w}$ istocie kilka splecionych ze sobą procesów, które toczyły się przed krzemienieckim sądem sprowadzonym do prywatnego miasteczka Leśniowa ${ }^{5}$.

Dokładniejsze przeanalizowanie tej sprawy nie pozwoli oczywiście wyczerpująco odpowiedzieć na pytanie, czym charakteryzowało się krzemienieckie prawo karne, jak przebiegało tamtejsze postępowanie sądowe, tym bardziej że obszerny tekst jest czystopisem, w którym - jak można przypuszczać - pominięto niektóre szczegóły postępowania. Wydaje się

tenże, Nadzór właścicieli wielkopolskiego Grodziska nad miejskim sądownictwem w sprawach kryminalnych w pierwszej połowie XVIII wieku, [w:] Historia testis temporum, lux veritatis, vita memoriae, nuntia vetutatis. Księga Jubileuszowa dedykowana Profesorowi Włodzimierzowi Kaczorowskiemu, red. E. Kozerska, M. Maciejewski, P. Stec, Opole 2015; tenże, "Stosując się do prawa wyraźnego..." Podstawy prawne wyroków kryminalnych grodziskiego sąu miejskiego w latach 1702-1756, „Studia Iuridica Lublinensia” 2013, t. XIX poświęcony pamięci Profesora Mariana Lecha Klementowskiego (1943-2013), red. M. Kuryłowicz, W. Witkowski; zob. też tenże, Sąd z Krzemieńca w wołyńskich miasteczkach. Z badań nad dziejami sądownictwa miejskiego w dawnej Polsce, [w:] Regnare - gubernare - administrare. Prace dedykowane profesorowi Jerzemu Malcowi z okazji 40-lecia pracy naukowej, red. S. Grodziski i A. Dziadzio, t. II, Z dziejów administracji, sądownictwa i nauki prawa, Kraków 2012. Sporo odmienności można też zauważyć w postępowaniu karnym stosowanym w Oświęcimiu (zob. tenże, Proces kryminalny w Oświęcimiu w I połowie XVIII w. Z badań nad prawem miejskim dawnej Rzeczypospolitej, [w:] Dyplomacja. Polityka. Prawo. Księga pamiatkowa ofiarowana Profesorowi Henrykowi Kocójowi w siedemdziesiąta rocznice urodzin, red. I. Panic, Katowice 2001. mieniec].

${ }^{3}$ Rkps w AGAD, Nabytki niedokumentowe Oddziału I, sygn. 58 [dalej cyt.: Krze-

${ }^{4}$ Szerzej o tym M. Mikołajczyk, Sąd z Krzemieńca..., s. 20-30.

${ }^{5}$ W Słowniku geograficznym Królestwa Polskiego i innych krajów słowiańskich, Warszawa 1880-1914, t. V, s. 176 miasteczko to występuje pod nazwą Leszniów. 
jednak, że nawet tak skromna próba przyjrzenia się tamtejszej praktyce wystarczy, by dostrzec pewne problemy, zasygnalizować nietypowe rozwiązania, odmienności w stosunku do dotychczas poczynionych spostrzeżeń, co z kolei pomoże odpowiednio ukierunkować dalsze badania.

3 listopada 1747 r. do Leśniowa, miasteczka należącego wówczas do podstolego wielkiego koronnego Stanisława Lubomirskiego zjechał „urząd majdeburski miasta Jego Królewskiej Mości Krzemieńca przysięgły", w skład którego wchodzili: burmistrz („president”) Bazyli Bożkiewicz, landwójt Teodor Jerozolimski ${ }^{6}$, rajcy Szymon Jakielewicz i Stefan Pawłowicz, wreszcie ławnik („przysięgły”) Łukasz Chytryk. Towarzyszył im szlachcic Jan Józef z Rudnickich Tysowski, pisarz miejski ${ }^{7}$. Wbrew oficjalnej nazwie („,urząd [...] przysięgły") nie był to sąd wójtowsko-ławniczy, lecz typowy dla małych miast połączony sąd ławy i rady miejskiej. Sąd ów był dość skromnie obsadzony; taka była jednak ówczesna praktyka - sądy miejskie sprowadzane do innych miejscowości zazwyczaj występowały w okrojonym składzie9. Liczba członków sadu krzemienieckiego była zresztą bardzo różna, nawet wtedy, gdy działał on „u siebie”, w Krzemieńcu ${ }^{10}$.

Sędziowie z Krzemieńca zostali zaproszeni przez władze Leśniowa wraz „z miastem całym i pospólstwem” 11 . W podobnych przypadkach sprowadzania sądu krzemienieckiego do któregoś z pobliskich miasteczek praktykowano nieraz (choć nie zawsze) poszerzanie składu sądzącego o miejscowych urzędników ${ }^{12}$. Skorzystano z tej możliwości również w interesującej nas sprawie i do składu sędziowskiego przybrano dwóch

${ }^{6} \mathrm{~W}$ innych zapiskach występuje on czasem także jako Jerozolimiec - por. Krzemieniec, s. 28 (nr 2, 1747 r.), 63 (nr 9, 1748 r.), 69 (nr 10, 1748 r.) lub Jerozolimowicz - Krzemieniec, s. 3 ( $\mathrm{nr} 1,1747$ r.).

${ }^{7}$ Krzemieniec, s. 42.

${ }^{8}$ Takie sądy tworzono zwłaszcza dla osądzenia poważniejszych spraw karnych i cywilnych (zob. np. S. Płaza, Historia prawa w Polsce na tle porównawczym, cz. I: X-XVIII w., Kraków 1997, s. 507; M. Mikołajczyk, Proces..., s. 29-33).

${ }^{9}$ M. Mikołajczyk, Proces..., s. 51-52, zob. też s. 44-46.

${ }^{10} \mathrm{~Np}$. w czerwcu 1748 r. sąd składał się z wójta dziedzicznego, „,namieśnika majdeburgii wójtostwa krzemienieckiego" oraz burmistrza, landwójta, dwóch rajców i trzech przysięgłych - Krzemieniec, s. 58 (nr 7). W sierpniu sędziów było ośmiu (namiestnik wójtostwa, burmistrz, landwójt, trzech rajców i dwóch ławników - Krzemieniec, s. 69, nr 10), we wrześniu - siedmiu (namiestnik wójtostwa, burmistrz, landwójt, dwóch rajców i dwóch ławników - Krzemieniec, s. 70, nr 11). Ale już w innych sprawach rozpatrywanych $\mathrm{w}$ tym roku sąd zasiadał w składzie cztero- (namiestnik wójtostwa, burmistrz, landwójt i rajca - Krzemieniec, s. 62, nr 8) bądź pięcioosobowym (namiestnik wójtostwa, burmistrz, landwójt, dwóch rajców - Krzemieniec, s. 63, nr 9).

${ }^{11}$ Krzemieniec, s. 42.

${ }^{12}$ M. Mikołajczyk, Sąd z Krzemieńca..., s. 26-30. 
leśniowskich burmistrzów: Michała Potorzyńskiego i Jana Zawackiego oraz trzech tutejszych starych rajców: Marcina Ryna, Semena Terlkowicza i Kondrata Oszarkowicza.

Sprawa toczyła się z oskarżenia instygatorów sądowych i ich delatorów. W charakterze owych współoskarżycieli występowało - jak możemy przypuszczać - całe miasteczko Leśniów ${ }^{13}$, z tym że taka „zbiorowa skarga" prawdopodobnie nie dotyczyła wszystkich obwinionych - na dalszych etapach postępowania przeciwko niektórym z nich jako oskarżyciele występowali bowiem wyłącznie pokrzywdzeni. Oskarżeni w tej sprawie to: Wasyl, syn Petrykowy, Andrzej Tkacz, zięć niejakiej Klimiszyny, Hapka, żona starego Petryka i Maryśka, żona Iwana, również syna Petrykowego. Zarzuty stawiane Wasylowi dotyczyły „wydarcia cudzych pasiek, koni kradzenia”, Andrzejowi zarzucano spalenie kilku folwarków i chałup, kobiety podejrzewane były natomiast o uprawianie czarów.

Występowanie stron procesowych sugeruje kontradyktoryjność postępowania. W aktach nie wspomniano jednak o wygłaszaniu skargi przez stronę powodową - niewykluczone, że istotnie zabrakło tego elementu postępowania ${ }^{14}$, być może uznano, że zastępuje go samo sprowadzenie sądu i prośba o rozpoznanie sprawy ${ }^{15}$. Pierwszą czynnością odnotowaną w protokole było przesłuchanie obwinionych (na razie tylko dwóch). Możemy przypuszczać, że nie były to ich pierwsze zeznania - prawdopodobnie zostali wcześniej przesłuchani przez miejscowe władze, jeden $\mathrm{z}$ oskarżonych postawionych przed sądem z Krzemieńca skorzystał bowiem z okazji, by sprostować poprzednio złożone wyjaśnienia ${ }^{16}$. Sędziowie, zgodnie z przyjętą $\mathrm{w}$ ówczesnych sądach miejskich praktyką ${ }^{17}$, „Z osobna” wzywali „przed oblicze swoje” poszczególnych aresztantów.

${ }^{13}$ Po informacji, że sąd krzemieniecki zjechał „,na afektacyją całego urzędu Leśniowskiego”, miasta i jego mieszkańców, wskazano, iż działo się to „na instancyją instygatorów sądowych i onych [podkreśl. - MM] delatorów". W dalszej części tekstu wspomniano, iż sąd zasiadł „dla rozsądzenia sprawy o zadanie przez całe miasto i instygatorów" (Krzemieniec, s. 42).

${ }^{14} \mathrm{~Np}$. w sprawie z sierpnia 1757 r. zapisano, że „instigator sądowy i jego dillator solennie się protestował i żalił na [...] niemiłosiernę zgubę wykradzenia potem spalenia i zasadzkę z widłami na zabicia przez [...] obżałowanych" (Krzemieniec, s. 34, nr 4).

${ }^{15}$ Możliwe jednak, że nie zamieszczono odpowiedniej informacji, uznając wniesienie skargi za oczywisty fragment postępowania. Zauważmy, że protokół, jako czystopis, nie odzwierciedla wiernie przebiegu procesu - zob. np. zamieszczoną w dalszej części artykułu uwagę o łącznym zapisaniu zeznań złożonych dobrowolnie i na torturach.

${ }^{16}$ Krzemieniec, s. 44.

${ }^{17}$ Por. M. Mikołajczyk, Proces..., s. 270. 
Nie można natomiast wykluczyć, że przesłuchiwani byli publicznie, a ich wypowiedzi utajniano jedynie przed pozostałymi obwinionymi ${ }^{18}$.

Jako pierwszy stanął przed sądem Wasyl Petrykowy. Zapytano go, czy przyznaje się „do wydarcia pasieki ulów pięć u parocha szczurowieckiego", a także do ewentualnych innych przestępstw. Odpowiedź Wasyla była obszerna. Opowiedział zatem, że gdy jeszcze chodził do szkoły próbował się włamać do kramnicy „niewiernego Żyda, obywatela leśniowskiego", nie zdołał jednak wejść do środka, przyłapano go bowiem na gorącym uczynku i oddano "do sądu zwierzchności dworskiej”. Sąd dominialny ukarał go "dworską karą" - zapewne chłostą. Później spokojnie mieszkał w domu rodzinnym („u ojca swego"), kiedy jednak się ożenił, "tegoż samego roku" ukradł konia. I tym razem Wasyl nie miał szczęścia - gdy próbował sprzedać skradzione zwierzę, rozpoznano je. Sprawcę ujęto i znów ukarano „dworską karą". Oskarżony twierdził, że wymierzone mu kary przyniosły pozytywny skutek, żałował złych uczynków i prowadził spokojny żywot. Dopiero w ostatnim czasie, ,"z jednej tylko malękoryi" (pewnie melancholii), spowodowanej odejściem żony i utratą majątku powrócił na złą drogę. Zaznaczał przy tym, że przyczyną nieszczęść, które go dotknęły było niesłuszne oskarżenie o kradzież konia, przed którym nie był w stanie się obronić. Prawdopodobnie - choć tego wyraźnie nie powiedział - zmuszono go do zapłaty wysokiego odszkodowania albo nałożono nań znaczne kary majątkowe, co doprowadziło do zrujnowania jego gospodarstwa, a w konsekwencji również życia rodzinnego. Być może uznał wówczas, że nie warto być uczciwym - w każdym razie postanowił kraść. Zamierzał zrabować miód z pszczelich uli; dobrze się do tego przygotował, zabrał odpowiednie naczynia oraz „kłaki do wykurzenia pczół”. W czółnie podpłynął Styrem pod pasiekę należącą do proboszcza szczurowieckiego i próbował odemknąć drzwi pasieczne. Ponieważ nie był w stanie owych drzwi otworzyć (pasieka najwyraźniej była solidnie zabezpieczona), przeżył załamanie nerwowe („wzięło” go „na sumienie i strach” i zaczął płakać), potem jednak się opanował i wówczas udało mu się sforsować ogrodzenie (wyłamał "kilka stawion”). W pasiece rozłupał pięć uli, napełnił naczynia miodem albo - co bardziej prawdopodobne - plastrami, zaniósł je do czółna i popłynął z łupem do Beresteczka. Miód sprzedał tamtejszemu Żydowi, a za część otrzymanych pieniędzy kupił sobie żupan i pas. Tymczasem do Beresteczka dotarła pogoń - złodziej prawdopodobnie nie działał zbyt ostrożnie, być może widziano $\mathrm{w}$ jakim kierunku popłynął $\mathrm{z}$ łupem. Wasyl schronił się przed

${ }_{18}$ Zauważmy, że jeden z przesłuchiwanych odwołał zeznania, którymi obciążył wcześniej innego człowieka „nie tylko przed Bogiem ale i przed ludem”, w dodatku potwierdził swe słowa podaniem ręki niesłusznie pomówionemu (Krzemieniec, s. 44). 
poszukującym go popem ze Szczurowców i towarzyszącymi mu ludźmi w stodole należącej do jego brata Iwana, ale pokrzywdzony duchowny odszukał go. Zaczął go bić po twarzy, znalazł też dowód rzeczowy - zza pazuchy złoczyńcy wyciągnął garść kłaków służących do okadzania pszczelich rojów. Wasyl próbował ratować swoją skórę wręczając "popu” otrzymany wcześniej od Żyda-pasera czerwony złoty. Ksiądz rzekomego okupu nie przyjął, lecz kazał ująć i związać Wasyla. Złodziej trafił najpierw do dworu, a potem do więzienia

Złoczyńca, opowiedziawszy o kradzieży miodu, powrócił jeszcze do sprawy konia, którego miał ponoć ukraść leśniczemu. Stanowczo odżegnywał się od popełnienia tego czynu, a także dość teatralnie (choć być może szczerze) odpuszczał winy niesłusznie go oskarżającym, przez których, w jego mniemaniu, stał się istotnie przestępcą. Odwołał też swe wcześniejsze pomówienia dotyczące niejakiego Iwana Charamacia, wynikające jedynie z "niesłusznej na niego zawziętej inwidyi własnej” i przywracał mu dobre imię (honor i sławę).

Nie był to jednak koniec przesłuchania - Wasyl poinformował bowiem sąd o dziwnych zdarzeniach związanych z jego rodziną. Oto gdy po ślubie obwinionego odbyły się pokładziny („,położyli nas spać”), siostra Wasyla, Maryśka „niejakową chusteczkę na dwoje przedarła” nad głowami nowożeńców, rzuciła jej połówki „na [...] głowy z obu stron i sama, dmuchnąwszy, poszła sobie". Wasyl miał jej wówczas powiedzieć, by sobie nachuchała "gdzie indziej", po czym nowo poślubiona żona uderzyła go "przez komplement po gębie”. Ponadto do matki oskarżonego dwukrotnie przychodziła jakaś Żydówka, „prosząc onę, ażeby dała paproci i czartowskiego ziobra"19.

Z notatki zamieszczonej na końcu tego fragmentu rękopisu wynika, że Wasyl Petrykowy był przesłuchany nie tylko dobrowolnie, ale także na torturach. Nie wiemy jednak, czy na męki został skazany natychmiast po owym dobrowolnym złożeniu zeznań, czy dopiero po jakimś czasie. Nie można też wykluczyć, że podobnie jak w innych sądach miejskich i tu po torturach następowało jeszcze jedno przesłuchanie obwinionego, z którym wiązało się niekiedy sporządzenie tzw. testamentu, czyli ostatecznego spisania zeznania złoczyńcy zakończonego oświadczeniem, że „z tym idzie na Sąd Boży" ${ }^{20}$. W każdym razie protokół zeznań stanowi najwyraźniej opracowaną na czysto sumę pozyskanych od oskarżonego informacji.

${ }^{19}$ Krzemieniec, k. 43-44 (przesłuchanie Wasyla Petrykowego).

${ }^{20}$ M. Mikołajczyk, Proces..., s. 317-319. Niewykluczone, że w naszym przypadku śladem takiego końcowego przesłuchania jest zwrot użyty przez oskarżonego Wasyla: „przed Sądem Boskim tym się świadczę" (Krzemieniec, s. 44). 
Kolejnym przesłuchiwanym złoczyńcą był Andrzej Tkacz, określany jako zięć znanej zapewne wszystkim w Leśniowie Klimiszyny (Kliminichy). Zarzucano mu zbrodnię podpalenia i przede wszystkim o nią był wypytywany, uznano jednak za stosowne zamieścić w protokole również szczegółowe dane dotyczące jego wcześniejszego życia - być może był osobą nieco mniej znaną w miasteczku niż poprzedni oskarżony. Urodził się w Stryju, ożenił w Sokalu, tam też osiadł na jakiś czas. Z pierwszą żoną miał pięcioro dzieci, później, zapewne po jej śmierci, przeprowadził się do Leśniowa, gdzie zajmował się swym tkackim rzemiosłem, tu też pojął za żonę „córkę Kliminiankę”. Urodziła mu jedno dziecko, potem jednak porzuciła męża. Andrzej, zostawiwszy dziecko u teściowej, udał się do Poczajowa, tam również pracował jako tkacz u swego ciotecznego brata. Oskarżony niewiele miał natomiast do powiedzenia o zarzucanym mu przestępstwie. Zdecydowanie nie przyznawał się do podpalenia folwarku i domu swej teściowej („tesczy”), od których zajęły się sąsiednie folwarki i chałupy. Aby dowieść prawdziwości swoich słów, pozwalał „się zdać na korporalną konfesatę".

Sąd najpierw jednak przesłuchał kilku świadków. Ich złożone pod przysięgą zeznania niewiele jednak wyjaśniły. Jedynie niejaki Fedko Kary zeznał, że oskarżony będąc u niego zapowiadał, że doprowadzi do zaboru lub aresztowania majątku teściowej i szwagra (miał zatem na myśli działania zgodne z prawem), nigdy jednak nie słyszał, by groził im podpaleniem. Trzej pozostali świadkowie zeznali jedynie, że "obżałowany" w różnych miejscach „oświadczał był”, iż będzie „u tesczy swej gościem”.

Po wysłuchaniu świadków wezwano oskarżonego (być może na czas inkwizycji musiał opuścić salę sądowa) i pytano go „po kilkanaście razów o popełnione paliaństwo". Andrzej stanowczo jednak twierdził, „że ani palił, ani się ni z kim namawiał, ani kogo do zakładania ognia nie posyłał”, nie zarzucał też świadkom „żadnego fałszu”, co zresztą jest zrozumiałe, zważywszy, że ich zeznania były dla niego korzystne.

W tej sytuacji, „nie mogąc wziąć niskąd żadnej słusznej relacyi do przyznania się" przez oskarżonego, sąd wydał dekret, mocą którego oddawał Andrzeja Tkacza „na korporalne konfesaty”. Obwiniony miał być "po trzykroć rozciąnniony i szynami palony”, co obserwować winni wszyscy członkowie sądu. Rodzaj tortur, a także sposób ich przeprowadzenia nie odbiegał w zasadzie od tego, co obserwujemy w innych sądach miejskich ${ }^{21}$, wydaje się natomiast, że sąd krzemieniecki nie widział

${ }^{21} \mathrm{O}$ torturach, polegających niemal wyłącznie na wyciąganiu kości ze stawów i przypalaniu boków delikwenta, o liczbie zadawanych cierpień, a także o obecności członków sądu w miejscu tortur zob. W. Maisel, Tortury..., s. 118-121; M. Mikołajczyk, Proces..., s. 301-316. 
potrzeby odkładania mąk, np. czekania do najbliższej nocy - wszystko wskazuje na to, iż do ich zadawania przystępowano natychmiast po wydaniu stosownego orzeczenia ${ }^{22}$. Ostatecznie poprzestano prawdopodobnie na samym trzykrotnym wyciąganiu kości ze stawów - tortury nie wniosły zresztą do sprawy nic nowego, oskarżony do niczego się nie przyznawał $\mathrm{i}$,to słowo w słowo zeznawał na korporalnych konfesatach, co i na dobrowolnych". Dlatego też sąd zdecydował się odroczyć postępowanie w jego sprawie ${ }^{23}$, zapowiadając, że dopiero „w ten czas postąpi tak, jak się będzie należało" 24 .

Mimo tej zapowiedzi przeprowadzono jeszcze jeden dowód dotyczący Andrzeja i zarzucanego mu czynu. Przesłuchano bowiem kolejnego świadka, niejakiego Franciszka Kotlińskiego, prawdopodobnie w obecności niedawno zwolnionego $\mathrm{z}$ tortur domniemanego podpalacza - w aktach zapisano bowiem, że zeznający „był stawiony naocznie obżałowanego". Kotliński twierdził, iż swego czasu (,w środę, przed Świętym Spasem") obwiniony przyszedł do niego „rano, zamoczony, boso”, trzymając w rękach buty i strzelbę („sztuciec”). Mówił, że idzie spod Brodów do Radkowa, nie wspominał natomiast nic o pobycie w Leśniowie. Żona Kotlińskiego przestrzegła męża, by nie „konserwował” gościa, gdyż jest on „zapalczywy i długą rękę ma”, gospodarz nakarmił jednak Andrzeja, pozwolił mu się przespać $\mathrm{w}$ stodole, a gdy po południu odchodził, dał mu na drogę chleb. Tkacz miał oświadczyć odprowadzającej go żonie Kotlińskiego, że gdyby tylko "swoję żonę zdybał", to by ",jej w piersi strzelił”, zapowiedział też, że uda się do Leśniowa.

Z dalszej części zeznań składanych przez Kotlińskiego wynika, że Andrzej przed odejściem prosił gospodarza o ołów "do nabicia sztućca”, mówiąc, że gdyby się miał „zdybać z szwagrem i z nim bić, nie miałby się „czym bronić".

Kotliński opowiadał też, że nazajutrz, w dniu pożaru, był w Leśniowie (poszedł tam na jarmark). Wypytywany przez mieszkańców miasteczka, opowiedział im o pobycie Andrzeja Tkacza u siebie i prowadzonych z nim rozmowach ${ }^{25}$.

${ }^{22}$ Dalsze zapiski dotyczące tej sprawy wskazują, iż po przeprowadzeniu tortur tego samego dnia powrócono do normalnych czynności sądowych. O nocnym torturowaniu złoczyńców zob. M. Mikołajczyk, Proces..., s. 299-300.

${ }^{23} \mathrm{~W}$ protokole stwierdzono, iż odroczenie to następuje "do terminu instygatora iudicii". Nie wiemy, czy pod tym zagadkowym dla nas zwrotem krył się konkretny dzień, czy też, co bardziej prawdopodobne, uznano, że o wznowieniu postępowania miał zdecydować oskarżyciel.

${ }^{24}$ Krzemieniec, s. 44-46 (zeznania A. Tkacza, zeznania świadków, informacja o torturach).

${ }^{25}$ Krzemieniec, s. 46-47 (zeznania F. Kotlińskiego). 
Oskarżony, wysłuchawszy zeznań, „na wszystkie punkta odpowiedział i sam na siebie tęż samą prawdę zeznał i niwczem nie negował ani się taił tego", nie wiadomo jednak, czy oświadczenie to było równoznaczne z przyznaniem się do podpalenia zabudowań ${ }^{26}$. W każdym razie sąd uznał, że wina oskarżonego powinna zostać poprzysiężona przez stronę powodowa, $\mathrm{w}$ aktach odnotowano bowiem złożenie przysięgi oskarżającej. Jurament taki wykonali: Jan Klimina, cechmistrz tkacki, Denisko Kliminka i Józko Moroz, występujący jako instygatorzy ${ }^{27}$, a wraz z nimi uczynili to pokrzywdzeni: Józko Chanenko, Wasyl Litowiński, Michałko Chanańko i Stefan Organista Stary, których zabudowania spłonęły podczas pożaru ${ }^{28}$. Warto zwrócić uwagę na ten szczegół, bo takie poprzysięganie udowodnionej już w inny sposób winy oskarżonego, znane prawu ziemskiemu, w znanej nam praktyce miejskiej raczej się nie pojawiało ${ }^{29}$.

Wyjaśniwszy sprawę podpalenia leśniowskich folwarków, sąd zajął się jedną $\mathrm{z}$ oskarżanych o czary kobiet. Tym razem nie zaczęto jednak od przesłuchania obwinionej, lecz najpierw wysłuchano złożonych pod przysięgą zeznań Franciszka Logoszewicza. Oskarżona Hapka, żona Petrykowa była jednak obecna w izbie sądowej, i w tym przypadku bowiem odnotowano, iż zeznający "naocznie tejże Petryczce dokazywał” to, czego był świadkiem. Opowiadał zatem, że swego czasu jechał wraz z nieżyjącym już panem Czarnkiem $\left(\right.$ Czarntkiem $\left.^{30}\right)$, gubernatorem leśniowskim oraz dwoma innymi mężczyznami. Widział wówczas Petrykową stojącą „pod oknyma” chałupy Stanisława Sysa. Gdy ją minęli, kobieta trzykrotnie się pochylała, zgarniała garściami ziemię i rzucała ją za odjeżdżającymi, za każdym razem plując. Świadek zbagatelizował - jak się wydaje - całe to zdarzenie ${ }^{31}$, ale $\mathrm{w}$ tym samym tygodniu gubernator nagle zachorował. Legoszowicz skojarzył wówczas niemoc gubernatora z wcześniejszym zachowaniem oskarżonej, chciał poinformować o tym chorego, ale

${ }^{26}$ Z dalszych zapisek wynika, że oskarżony przyznał się do winy dopiero po wysłuchaniu skazującego wyroku (Krzemieniec, s. 57).

${ }^{27}$ Zapewne były to osoby powołane ad hoc do pełnienia funkcji instygatora sądowego, choć nie można wykluczyć, że byli to oskarżyciele prywatni (w małych miastach też określani niekiedy jako instygatorzy - por. M. Mikołajczyk, Proces..., s. 89-96.

${ }^{28}$ Krzemieniec, s. 47.

${ }^{29} \mathrm{~W}$ prawie ziemskim przysięgę taką wykonywano jednak po wydaniu wyroku, choć, być może, przed jego ogłoszeniem (zob. A. Abramski, Sąownictwo podczas konfederacji w Polsce (1672-1793), Katowice 1986, s. 122 oraz M. Mikołajczyk, Proces..., s. 374; por. także przysięgę składaną w głośnym procesie Jerzego Sebastiana Lubomirskiego w 1664 r. - W. Czermak, Sprawa Lubomirskiego w roku 1664, [w:] tenże, Ostatnie lata Jana Kazimierza, oprac. A. Kersten, Warszawa 1972, s. 216-217).

${ }^{30}$ Odczyt niepewny.

${ }^{31}$ Zeznawał: „, tak jem to jedno uważał, a drugie nic mi było do tego" (Krzemieniec, s. 47). 
nie został doń dopuszczony, potem wysłano go w podróż, a gdy wrócił, gubernator już nie żył. Dlatego też, chociaż wcześniej nikomu o tym nie mówił, teraz ma obowiązek dowieść winy oskarżonej Hapki ${ }^{32}$.

Obwiniona, odpowiadając na owo świadectwo, oświadczyła, że do niczego się nie przyznaje, nie parała się czarami, nikomu też nie zadała trucizny. W chwili zatrzymania nie miała $\mathrm{w}$ kieszeni żadnych podejrzanych rzeczy, tylko „kilka kąsków chusteczek, sukna, nici białych itp., którymi to rzeczami ",nikogo [...] nie oczarowała”, natomiast rzekomo znalezione przy niej włosy i nasiona lulka ${ }^{33}$ zostały jej podrzucone przez ludzi, którzy ją szarpali, biorąc do aresztu.

"Wiele razów inkwirowana, nie znała się do niczego", chociaż świadek Logoszewicz "powtórnie i po trzecie” dowodził jej, że zdarzenie, o którym opowiadał rzeczywiście miało miejsce. „W tym momencie obżałowana rzuciła się do świadka, mówiąc: »A tyś to taki następca życia mego, poczekajże no ty! «". Zaczęła bić palcem po nosie (chyba swoim), jednocześnie odgrażając się Logoszewiczowi.

Świadek przypomniał wówczas inne podejrzane zdarzenie. Oto obwiniona miała go kiedyś „na mieście” prosić na gorzałkę, przy czym okrążyła go trzy razy, w gospodzie zaś miała mu mówić: „,azaż nie tyś się u mnie prosił?" Oskarżona nie zaprzeczyła, że wypowiadała takie słowa, chociaż - jak twierdziła - nie wie, jaka była przyczyna owego proszenia ${ }^{34}$.

Sąd, wysłuchawszy zeznań i konfrontacji, stwierdził, że skoro obżałowana nie chce się przyznać "dobrowolnie do większych popełnionych czarów" i wyrządzenia przez nie szkód na zdrowiu i na życiu, potwierdza jedynie, że rzucała ziemią „za nieboszczykiem Czarntkiem” i jadącymi z nimi ludźmi „ze złości” 35 , zatem powinna być „dla lepszej informacyi wzdana [...] na korporalne konfessata". O rodzaju tortur zdecydować mieli członkowie sądu do tej czynności oddelegowani ${ }^{36}$.

Przeprowadzane 3 listopada czynności sąd zamknął wydaniem wyroku dotyczącego jednego z oskarżonych, Wasyla Petrykowego (Petrykowa). Jego sprawa niewątpliwie dojrzała do ostatecznego rozstrzygnięcia.

Po dokładnym przeanalizowaniu dowodów, w tym zwłaszcza dobrowolnych i składanych na torturach zeznań obwinionego, sąd wziął pod uwagę

${ }^{32}$ Krzemieniec, s. 47 (zeznanie F. Logoszewicza).

${ }^{33}$ Są one silnie trujące.

${ }^{34}$ Krzemieniec, s. 47-48.

${ }^{35} \mathrm{Z}$ wcześniejszych zapisek przyznanie to jednoznacznie nie wynika, być może jednak notatka o potwierdzeniu słów świadka odnosiła się i do owego zdarzenia.

${ }^{36}$ Krzemieniec, s. 48. Zauważmy, że również w nieco wcześniejszej sprawie, rozpatrywanej wiosną $1747 \mathrm{r}$. w Zasławiu, ostateczna decyzja o sposobie męczenia domniemanych złoczyńców należała do sędziów delegowanych (Krzemieniec, s. 13, nr 1). 
nie tylko zarzucane mu wyłupanie pszczelich uli, ale także jego wcześniejsze życie i postępki. W dekrecie przypomniano zatem zarówno próbę włamania się do „kramnicy żydowskiej”, jak i późniejszą kradzież konia. Podkreślono, że „nie chcąc pamiętać na pierwszę i drugę karę, po trzecie dopuścił się złych ekscesów", kradnąc miód z pasieki szczurowieckiego popa. Opisano dość dokładnie owo zdarzenie, przydając również tłumaczenie oskarżonego, iż do popełnienia tego przestępstwa skłoniło go niesłuszne oskarżenie o kradzież konia. Sąd stwierdził, że Wasyl powinien być „,za popełnione złodziejstwo podług prawa majdeburskiego tak karany, jako obszerniej artykuły w Saksonie i w Porządku za wydarcie pasiek i zgubienie pczół opisują". Prawdopodobnie odwoływano się tu nie tyle do Zwierciadła saskiego i dzieła Bartłomieja Groickiego Porządek sąów i spraw miejskich prawa majdeburskiego w Koronie Polskiej, ile do zwyczajowej kary wytoczenia jelit stosowanej wobec złodziei miodu ${ }^{37}$. Sąd jednak, "będąc przychylnym ostatniej woli i życia kresu" oskarżonego, darował mu okrutne kary i skazał go ,jedynie" na ścięcie mieczem. Egzekucja miała się odbyć w najbliższy piątek ${ }^{38}$. Co ciekawe, sędziowie krzemienieccy ${ }^{39}$ nie ograniczyli się do „wyrzeczenia o winie i karze". Na wniosek obwinionego, który, idąc na śmierć, prosił sędziów, by zechcieli „w gruntach i domostwie jego [...] uczynić pomiarkowanie i rozporządzenia", postanowiono, że każdy kto obejmie domostwo i grunty skazańca "powinien będzie wszelkie długi juramentem zeznane płacić". Postanowienie to dotyczyło zapewne długów, które mogą się pojawić w przyszłości i które wierzyciele poprą przysięga, na końcu orzeczenia wskazano bowiem wyraźnie kilka osób, którym należało spłacić długi skazanego, dokładnie też określono należne im sumy.

Sąd postanowił też zamknąć sprawę kradzieży konia należącego do leśniczego. Skoro pokrzywdzony nie był w stanie dowieść, że właśnie Wasyl popełnił to przestępstwo, nie chciał też popierać oskarżenia ani złożyć przysięgi oskarżającej, to uznano, że nie należy mu się żadne odszkodowanie. Nakazano mu zwrócić pieniądze, które już otrzymał od rzekomego sprawcy, przy czym postanowiono, że jedna połowa tej kwoty powinna być przeznaczona na msze za duszę straconego, a druga winna przypaść jego osieroconym dzieciom. Tymże dzieciom oraz ich matce na-

${ }^{37}$ Por. W. Maisel, Poznańskie prawo..., s. 117-131; M. Mikołajczyk, Przestępstwo i kara..., s. 198.

${ }^{38}$ Stosunkowo często właśnie ten dzień tygodnia obierano jako najwłaściwszy do wykonania kary śmierci (M. Mikołajczyk, Proces..., s. 535).

${ }^{39}$ Być może w wydaniu wyroku uczestniczyli też przybrani do składu sądu członkowie leśniowskich władz miejskich - nie jest to jednak oczywiste. Szerzej na ten temat M. Mikołajczyk, Sąd z Krzemieńca..., s. 28-29). 
leżą się również nieruchomości skazanego, „wszelkie jego grunta, sianożęci, ogrody, chałupa i różne ruchomości" 40 .

Warto zwrócić uwage na owe dodatkowe postanowienia zawarte w wyroku, bo chociaż z rzadka zdarzało się, że sądy miejskie przy okazji rozpatrywania sprawy karnej rozstrzygały też pewne kwestie majątkowe $^{41}$, w tym wypadku jednak wyjątkowo szczegółowo zajęto się cywilnoprawnymi konsekwencjami śmierci oskarżonego.

Być może tego samego dnia, a być może dopiero parę dni później, 6 listopada $1747 \mathrm{r}^{42}$ sąd zajął się ostatnią z obwinionych, Maryśką, żoną „Iwana, syna Petrykowego", czyli bratową dopiero co skazanego Wasyla. I tym razem, zanim udzielono głosu oskarżonej, wysłuchano zeznań świadków, które miały potwierdzić zarzuty instygatora sądowego ${ }^{43}$.

Iwan Bałdurec, mielnik (młynarz) leśniowski zaznał, iż kiedyś, przed laty ${ }^{44}$, we czwartek, jego synowie, Fedko i Matwiej widzieli na końcu grobli leśniowskiej, pod cmentarzem, „u piaseckiego mostu” dwie leżące kobiety, dwie Iwanichy (czyli żony Iwanów) - Maryśkę, żonę Iwana Petrykowego oraz starą Iwanichę Mielniczkę. Mielniczka była ubrana na czarno, a Maryśka na zielono. Chłopcy od razu powiedzieli o tym stojącemu na grobli ojcu, który poszedł zobaczyć kobiety, nie odezwał się jednak do nich, lecz zajął się swą pracą. Po dłuższym czasie zobaczył jednak „biegnącego Wasyla Charamacia z wielkim gwałtem”. „W tym momencie porwawszy się pomienione kobity z miejsca swego, na którym leżeli, poszli przeciwko Charamacia". Wasyl próbował zatrzymać obie niewiasty, nie utrzymał co prawda Mielniczki, ale udało mu się zaprowadzić do dworu żonę Iwana Petrykowego. Świadek dodał też, że wszyscy Petrykowowie mieli do niego pretensje, podejrzewając niesłusznie, iż to on dał znać do dworu o leżących na grobli kobietach. Ponadto dwa dni później syn Iwana, Matwiej nagle „przy obiedzie zachorował na wielką chorobę”. Nie była to chyba jednak padaczka, lecz jakiś rodzaj paraliżu, świadek twierdził bowiem, że chłopcu „odjęło nogi, ręce”. Do Matwieja sprowadzono

\footnotetext{
${ }^{40}$ Krzemieniec, s. 50-51.

${ }^{41}$ Owe nieliczne orzeczenia dotyczyły głównie kwestii odszkodowań związanych z popełnieniem przestępstwa (M. Mikołajczyk, Proces..., s. 481).

42 Pierwsze zapiski dotyczące oskarżonej Maryśki pozbawione są daty, co sugerowałoby, że odpowiednie czynności (wysłuchanie świadków) przeprowadzono w tym samym dniu, w którym zapadł wyrok na Wasyla Petrykowego. Jednak przesłuchanie oskarżonej opatrzono datą 6 XI 1747 r., użyte zaś wówczas zwroty sugerują (choć nie jednoznacznie), iż nastąpiło ono zaraz po złożeniu zeznań przez świadków (Krzemieniec, s. 53).

${ }^{43} \mathrm{Tu}$ instygator występuje wyraźnie jako „instygator urzędu leśniowskiego” (Krzemieniec, s. 52).

${ }^{44} \mathrm{O}$ tym, że zdarzenie nastąpiło dość dawno dowiadujemy się dopiero z wyroku (Krzemieniec, s. 53-54).
} 
kapłana i chłopak „przez boską moc był uzdrowiony”. Tego samego dnia jednak, "przy wieczerzy”, taka sama niemoc „opanowała” drugiego syna. Ojciec i w tym wypadku prosił Boga o ratunek. Świadek niedwuznacznie sugerował zatem istnienie związku między podejrzanym zachowaniem kobiet, ich ujęciem i niesłusznym zarzutem donosu, a chorobą synów, z której wyjść mogli tylko dzięki boskiej interwencji.

Kolejnym świadkiem była Helena Kostycha, żona przysiężnego. Opowiadała, iż w ów czwartek, gdy prała chusty na grobli, również widziała Iwanichę (a może i obie kobiety) idącą przez kładki w stronę piasków położonych poniżej grobli. Młynarz Iwan Bałdurec, podszedłszy do Heleny, miał stwierdzić: „a widzisz matko, że już poszli czartów roznosić". Helena dość lekceważąco odparła: „a kiedy by to oni mieli czartów roznosić?" Kiedy jednak wracała do domu, zauważyła stojącą na wałach i płaczącą Charamacichę. Zaczęła ją wówczas pocieszać, mówiąc, iż nie ma już powodu do płaczu, jako że - jak mówił młynarz - jej czarci (którzy zapewne ją trapili) zostali przeniesieni gdzie indziej.

Trzecim świadkiem był mąż owej Charamacichy, Wasyl Charamać (Charamaciak). $Z$ dalszych zapisek wynika zreszta, że był on również powodem - prywatnym oskarżycielem $w$ tej sprawie. Twierdził, że stara Kostycha dała znaćjego żonie, iż „Iwanicha Petrykowego syna żona i Iwanicha Mielniczka" właśnie poszły rzucić czary na rodzinę Charamaciów. Wasyl czym prędzej pobiegł na groblę w stronę cmentarzyska i tam rzeczywiście zastał nagą Marusię, żonę Petrykową i odzianą w katanę drugą Iwanichę. Obie kobiety „stali nad grobem pogrzebionym”, przy czym Mielniczka nakryła się „połą z katanki”. Gdy został zauważony, Marusia zaczęła się ubierać. Wówczas, nie bez trudności, zaprowadził ją do młyna, a stamtąd "dworscy ludzie", którzy wraz z innymi mieszkańcami Leśniowa, zaalarmowanymi "gwałtem wielkim" pojawili się na grobli, „poprowadzili je do dworu". Tymczasem oburzony Iwan Petrykow zaatakował Charamacia, i niemal go nie zabił. Żalił się też świadek, że Iwan do tej pory ani nie został ukarany, ani też nie doszło do pojednania i zadośćuczynienia ${ }^{45}$.

Z owych dość pogmatwanych relacji wyłania się obraz czarownic, które być może wcześniej, a być może dopiero odprawiając gusła na grobli, miały nasłać diabłów na rodzinę Charamaciów.

Do zeznań świadków ustosunkowała się oskarżona (,stała naocznie przeciwko inkwizycyi wywiedzionej mówić"). Nie złożyła żadnych obszerniejszych zeznań, natomiast zdecydowanie nie przyznawała się do stawianych jej zarzutów, twierdziła, iż "nikogo nie czarowała" ani nie miała takiego zamiaru, stanowczo też zaprzeczała, by była na cmentarzysku.

${ }^{45}$ Krzemieniec, s. 53-54 (zeznania świadków I. Bałdurca, H. Kostychy, W. Charamacia). 
Po wysłuchaniu obwinionej sąd nie prowadził już dalszego postępowania dowodowego, lecz od razu wydał końcowy wyrok. Przypomniał $\mathrm{w}$ nim opisane w zeznaniach zdarzenia $\mathrm{z}$,przeszłych lat", rzekome przyłapanie oskarżonej i drugiej Iwanichy "leżących pod cmentarzyskiem” oraz skojarzoną z nim chorobę dzieci młynarza Iwana Bałdurca. Streszczono też zeznania Heleny Kostychy i Wasyla Charamacia. Sąd jednak z wyraźnym dystansem podszedł do zasłyszanych opowieści, wplatając do relacji o nich odpowiednie słowa (np. „niby [...] na wielką chorobę zachorowali”, „że niby dał znać do dworu” itp.). W dalszej części orzeczenia zwrócono też uwagę na "zawziętości i ludzkie nienawiści”.

Sprawa trafiła wówczas do sądu dominialnego (oskarżoną, jak pamiętamy, odprowadzono do zamku (dworu) leśniowskiego), nie wiadomo jednak, czy wydano wtedy jakieś orzeczenie. Co prawda z dalszej części wyroku wynika, iż sąd leśniowski orzekł swego czasu dotąd nie wykonane kary, nie sposób jednak ustalić, czy dotyczyły one głównych zarzutów przeciwko obwinionej, czy też pozostawały z nimi jedynie w luźnym związku. Sąd krzemieniecki stwierdził wprawdzie, że oskarżycielom wówczas "stało się zadosyć i sprawiedliwości satysfakcyja”, ale jednocześnie zaznaczał, iż powód Wasyl Charamać skarży się, „że w tej sprawie dotąd nie mieli dekretu finalnej decyzyi", dodawał też, że w owym postępowaniu zabrakło „aktora i instygatora” - czyli najwyraźniej nikt jej nie popierał. W każdym razie Wasyl Charamać, któremu „w przeszłych latach nie stała się satysfakcyja [...] znowił dawnę niejakowę pretensyję".

Jak się jednak okazało, obie strony nie były w stanie niczego dowieść, przede wszystkim zaś nie udowodniono, „ażeby teraźniejszymi czasy miała się żona Iwana Petrykowego obchodzić złemi akcjami i nierządnemi czarami i fabułami”. Mimo to sąd wziął pod uwagę także "wszystkie cikumstancyje" opisane w dekretach miejscowego, leśniowskiego urzędu miejskiego z 8 stycznia 1745 r. i przypomniał, że wówczas za jakieś obraźliwe wypowiedzi czy też wyzwiska („nieutrzymanie języka poblikowania się") oskarżona Maryśka została skazana na 100 rózg. Wyroku nie wykonano, ale sąd krzemieniecki utrzymał go w mocy, podwyższając zarazem karę do 200 uderzeń. Chłosta wykonana miała być przez „pachołka urzędowego, jeszcze nie publice, tylko pod domem sądowym", w czym kryła się oczywiście groźba, że następne niewłaściwe zachowania pociągną za sobą surowszą karę. Zapowiedziano też, że jeśli w przyszłości udowodniono by jej zajmowanie się „fabułami lub jakiemi nierządnemi zabawami” powinna być „,żywo ogniem palona”. Zobowiązano też męża obwinionej, Iwana Petrykowa, do stawienia pięciu wiarygodnych mieszczan leśniowskich, ani z nią, ani z nim nie spokrewnionych, którzy będą mogli poręczyć, iż Maryśka Petrykowa nie będzie się w żaden sposób na kimkolwiek mścić za to, 
co ją spotkało. Gdyby udowodniono jej takie złe uczynki, ukarana powinna zostać nie tylko ona, ale także jej mąż oraz poręczyciele.

W końcowej części dekretu znalazły się postanowienia o charakterze prejudykatu, pozostające w pewnym związku ze sprawą rzekomej czarownicy. Sądowi doniesiono bowiem, „żałując się gdzie nie na których ludzi", mieszkańców Leśniowa, którzy, obmawiając swych bliźnich, zwykli „nie tylko o żywych, ale i o umarłych źle myślić, po gospodach przy kwatyrkach lub posiedzeniu jakiem, życiem, śmiercią osądzone, cenzorować, poblikować, przytyki, zniewagi dawać, przechwałki czynić". Wprawdzie ukarze ich za te czyny "sam Bóg niemiłosierny" ale, zważywszy, że na władzach również spoczywa obowiązek zapobiegania takim zjawiskom, sędziowie krzemienieccy postanowili, że występni, zanim staną przed sądem boskim, powinni być postraszeni "sądem i karą świecką”. Każdy zatem, "kto by miał zmawiać, zadawać jakowe niewłaściwe słowa” dotykające czyjejś sławy i honoru winien złożyć do kościoła 50 funtów wosku i 50 grzywien, leżeć w tymże kościele krzyżem przez pięć mszy świętych, po tyle samo wosku i grzywien oddać obu miejscowym cerkwiom, wreszcie zapłacić 100 grzywien na rzecz skarbu właściciela miasta. Gdyby stan majątkowy skazanego nie pozwolił na uiszczenie owych bardzo dotkliwych kar majątkowych, winien on być „,na ciele i wszelkich ruchomościach swoich serio karany". Na koniec dość wyraźnie wskazano, że prejudykat odnosi się przede wszystkim do rodziny Petrykowów, "cały magistrat" bowiem "temu Iwanowi, synowi Petrykowemu, żonie i dzieciom jego [...] jednym słowem” uznał „swoję mieć godność" 46 .

6 listapada wydano też dekret w sprawie Andrzeja Tkacza, zięcia wdowy Kliminichy. Wcześniej oskarżyciele prawdopodobnie złożyli przysięgę potwierdzającą winę oskarżonego.

W wyroku dość dokładnie przedstawiono stan faktyczny ustalony na podstawie zebranych dowodów. Szczegółowo opisano „wizytę" złożoną przez oskarżonego zamieszkałemu w Radkowie Franciszkowi Kotlińskiemu, zwrócono uwagę na to, że Andrzej prosił wówczas o ołów „,do nabicia strzelby", co pozwoliłoby mu obronić się przed szwagrem, żonie zaś Kotlińskiego wyznał, że udaje się do Leśniowa i że chętnie zastrzeliłby swoją własną małżonkę. Zaznaczono, iż oskarżony temu nie zaprzeczał, nie chciał się natomiast przyznać do podpalenia zabudowań należących do jego teściowej. Sąd ustalił jednak, że świadkowie wykazali, iż obwiniony zapowiadał swe odwiedziny u tejże teściowej "przed Preczystą", a stąd wypływa "słuszna racyja i podobieństwo tego obżałowanego do zapalenia tesczy swojej, z której zgorzało folwarków cztery i chałup trzy".

\footnotetext{
${ }^{46}$ Krzemieniec, s. 53-54 (wyjaśnienia oskarżonej Maryśki i wyrok w jej sprawie).
} 
Wobec braku jednoznacznych dowodów wykorzystano zatem poszlakę, chociaż przyznano, że i ją obwiniony próbował obalić, twierdząc, że zapowiedziane odwiedziny u teściowej miały być odwiedzinami w dosłownym znaczeniu („,się chwalił być dobrym do tesczy gościem, a nie złym”), że za pomocą broni palnej zamierzał się jedynie bronić przed napaścią szwagrów i że, wcześniej „żonie dawszy w piersi”, chciał pójść w świat.

Do podpalenia oskarżony nie chciał się przyznać również na torturach. Sąd nie dał mu jednak wiary, wskazał, że owo "paliaństwo" świadkowie $\mathrm{mu}$ „naocznie inkwizycyjami dowodzą", a ,instygatorowie przysięgą dokazują" i domagają się, by „na śmierć był sądzony” i dlatego, odwołując się raz jeszcze do owej ,"instygatorów zawziętości”, skazał obwinionego na karę główną. Przywołano przy tym przepisy Zwierciadła saskiego - jak się wydaje zupełnie przypadkowe, nie odnoszące się do zarzucanej oskarżonemu zbrodni ${ }^{47}$ - twierdzono jednak, że wedle nich podpalacz winien być żywcem spalony. Obawiając się wszakże, by złoczyńca, „,w ogniu żywym będąc, nie wpad[ł] w desperacyją w złe zamysły", darował mu tak surową karę. Ostatecznie, „za popełnione założenie ognia i spalenie dóbr ludzkich, dla przykładu inszych" miał być „za Bramą Berestecką, między drogami” ścięty mieczem, ,"a na potem ogniem na proch spalony".

Gdy ogłoszono wyrok ${ }^{48}$, obwiniony, „widząc nie żarty i nie uchodząc kary, stanąwszy osobiście, przyznał się, że popełnił zarzucane mu „paliaństwo", czyniąc to "ni z czyjej namowy, tylko z swego umysłu i zawziętości". Wobec owego przyznania się do winy, sąd darował mu spalenie ciała i nakazał, by obwiniony został ścięty na placu i pochowany na cmentarzu ${ }^{49}$.

Prawdopodobnie ostatnią czynnością sądu krzemienieckiego w Leśniowie było wykonanie postanowienia o oddaniu na tortury Hapki Petrykowej. Przeprowadzono je - jak się wydaje - dopiero 8 listopada ${ }^{50}$. Nie wiadomo, ilu sędziów asystowało przy torturach - podano jednak, że byli wśród nich zarówno rajcy, jak i ławnicy, odnotowano też obecność instygatora (w tym wypadku miano na myśli zapewne oskarżyciela prywatnego).

${ }^{47}$ Przywołano tu - chyba na chybił trafił art. 8 i 38 z księgi I oraz art. 17 z księgi III, pominięto natomiast traktujący rzeczywiście o podpaleniu (i łamaniu podpalacza kołem) art. 13 z księgi II. Por. Sachsenspiegel. Landrecht und Lehnrecht, wyd. F. Ebel, Stuttgart 2005, s. $35,52,81-82,125$.

${ }^{48}$ Tak chyba należy bowiem rozumieć zwrot: „po załączonym dekrecie [...] sam ustnie przyznał się" (Krzemieniec, s. 57).

${ }^{49}$ Krzemieniec, s. 56-57 (wyrok w sprawie Iwana Tkacza).

${ }^{50}$ Kolejność zapisek wskazywałaby, iż tortury przeprowadzono jeszcze tego samego dnia. Przeczy temu jednak podana w zapisce data. O tym, że męki nastąpiły kilka dni później świadczy też zamieszczona w niej wzmianka o postanowieniu sądu z 3 XI (byłaby zbędna, gdyby do męczenia oskarżonej przystąpiono natychmiast). 
Przed sąd przyprowadzono oskarżona, która dalej do niczego nie chciała się przyznać. Wówczas tenże „sąd, reformując się do prawa, kazał [...] dekret superius ferowany ad effectum korporalnej inkwizycyi [...] przyprowadzić". Hapka, oddana w ręce kata, „po trzykroć [...] ciągniona i świcami po trosze po bokach straszona”, wypytywana przez „instygatora", nic nowego jednak nie dodała, powtarzała tylko to, co powiedziała już dobrowolnie i, „wołając, mówiła: »nie znam się«". Za godne odnotowania uznano jedynie jej wyraźne stwierdzenie, iż „rzucała ziemię ze złości" za jadącym gubernatorem i jego towarzyszami ${ }^{51}$.

Nie wiemy jak zakończyła się sprawa Hapki - w aktach brakuje wyroku - być może jednak uparte nieprzyznawanie się do winy wystarczyło, by zaniechać dalszego postępowania i tym samym je umorzyć.

Jak już wspomnieliśmy, toczące się na początku listopada $1747 \mathrm{r}$. $\mathrm{w}$ Leśniowie postępowanie $\mathrm{w}$ istocie stanowiło kilka dość luźno ze sobą splecionych procesów. Można by więc traktować je jako rozciągnięte na dwa lub trzy dni posiedzenia sądu, podczas których rozpatrywano cztery odrębne sprawy. Jednak pisarz sporządzający czystopis protokołu wyraźnie potraktował owo postępowanie jako jedną sprawę - być może zaważyło tu przeplatanie się czynności podejmowanych w stosunku do poszczególnych podsądnych, z pewnością zaś związki rodzinne zachodzące między większością oskarżonych. Nie było to zresztą nietypowe podejście - w praktyce innych sądów miejskich zdarzało się np. wydawanie wspólnych dekretów, mimo iż postępowanie przeciwko poszczególnym obwinionym było wszczynane $\mathrm{w}$ różnym czasie, orzekanie co do części oskarżonych, podczas gdy w stosunku do innych prowadzono jeszcze postępowanie dowodowe, a nawet łączenie zupełnie różnych spraw, dotyczących niepowiązanych ze sobą osób i wydawanie wspólnego wyroku ${ }^{52}$. W każdym razie postępowanie toczące się w Leśniowie było bardzo dalekie od formalizmu. Nie trzymano się sztywno kolejności przesłuchań, zeznania świadków następowały po wysłuchaniu obwinionego, ale mogły też je poprzedzać (zwłaszcza gdy spodziewano się, że oskarżony będzie wszystkiemu zaprzeczał). Wśród zeznających pod przysięgą świadków pojawili się także „instygatorzy”, czyli prywatni oskarżyciele, mimo iż prawo miejskie nie pozwalało, by ta sama osoba świadczyła i oskarża$\mathfrak{l a}^{53}$. Co więcej, niektóre zeznania świadków traktowano jako formę skar-

${ }^{51}$ Krzemieniec, s. 49.

${ }^{52}$ M. Mikołajczyk, Proces..., s. 461-462; tenże, Z dziejów zbrodni i kary w dawnej Polsce. Żywot i proces Antoniego Złotkowskiego, zbójnika z Pcimia, Katowice 2001, s. 51-99.

${ }^{53} \mathrm{~W}$ praktyce przesłuchanie delatora jako świadka zdarzało się zupełnie wyjątkowo i było przy tym kwestionowane (M. Mikołajczyk, Proces..., s. 343, 365-367; tenże, Jak obronić oskarżona o czary. Mowy procesowe z 1655 roku w sprawie Gertrudy Zagrodzkiej, [w:] Z dziejów 
gi czy postawienia zarzutów. W postępowaniu niewątpliwie zachowano zasady skargowości i kontradyktoryjności (zauważmy choćby dużą rolę oskarżycieli i składanych przez nich przysiąg), ale konkurowała z nimi znaczna aktywność sądu, wyraźnie zmierzającego do wszechstronnego rozpoznania sprawy. Ów brak formalizmu niewątpliwie sprzyjał sprawności postępowania, ekonomii procesowej, nie wiemy natomiast, czy było to świadome odstępowanie od reguł postępowania, czy też konsekwencja nieznajomości prawa, która zmuszała sędziów do szukania na własną rękę najprostszych i najwygodniejszych metod działania.

Interesujące i warte dokładniejszego zbadania wydaje się poprzysięganie winy oskarżonego, umożliwiające orzeczenie wobec niego kar kryminalnych. Ciekawe są też wydawane przez sąd krzemieniecki wyroki, zwłaszcza ich nietypowe fragmenty, nie odnoszące się bezpośrednio do głównego przedmiotu sprawy. W sprawie pojawia się rozbudowany prejudykat, mamy też obszerne postanowienia dotyczące różnych kwestii cywilnoprawnych będących konsekwencją popełnienia przestępstwa oraz skazania jego sprawcy. Najwyraźniej wychodzono z założenia, że postępowanie należy doprowadzić do końca, nie pozostawiać nierozstrzygniętych kwestii, które mogłyby się stać zarzewiem nowych konfliktów. Pod tym względem proces z 1747 r. wydaje się dość wyjątkowy; takie dodatkowe postanowienia zarówno w Krzemieńcu ${ }^{54}$, jak i w innych miastach stanowiły bowiem rzadkość. Na pewno jednak problem różnych ubocznych postanowień wyroków karnych wydawanych w małych miastach zasługuje na szczegółowe badania.

Leśniowski proces wskazuje też na potrzebę badań nad przestępczością we wsiach i małych miasteczkach przedrozbiorowej Rzeczypospolitej. Zwrócić uwagę należałoby zwłaszcza na to, w jakim stopniu przestępczość ta miała zawodowy charakter, a w jakim mamy do czynienia z działaniami okazjonalnymi, podejmowanymi sporadycznie. Leśniowski proces wskazywałby raczej na amatorski charakter przestępnych poczynań, dużą nieporadność złoczyńców, ich nieumiejętność maskowania się, zacierania śladów, jednak prowadzone dotąd badania - choćby nad góralskim zbójnictwem - wskazywałyby, że w sprzyjających warunkach również wiejscy przestępcy mogli rozwijać swą działalność na dużą skalę, stając się w swym fachu profesjonalistami ${ }^{55}$.

kultury prawnej. Studia ofiarowane Profesorowi Juliuszowi Bardachowi w dziewięćdziesięciolecie urodzin, Warszawa 2004, s. 392-393, 396-398).

${ }^{54}$ Por. np. Krzemieniec, s. 242-243 (nr 56, 1762 r.).

${ }^{55}$ Por. M. Kamler, Zbójnictwo i rozbój w Beskidach od drugiej połowy XVI do pierwszej połowy XVIII wieku, [w:] Społeczeństwo staropolskie. Seria nowa, t. II, Społeczeństwo a przestępczość, Warszawa 2009, s. 187-236; zob. też M. Mikołajczyk, Z dziejów zbrodni..., s. 18-50; tenże, Tomasza Piotrowskiego żywot niegodziwy. Przyczynek do dziejów przestępczości w Polsce wieku Oświecenia, „Z Dziejów Prawa” 2009, t. II (X), s. 47-74. 
Ciekawy i wart osobnych badań wydaje się wreszcie język krzemienieckich akt sądowych. Sporo w nim regionalizmów, ale widoczne są również starania pisarza, by sporządzane przezeń dokumenty były „uczone", prawnicze, wywierały odpowiednie wrażenie zarówno na zwykłych mieszkańcach Krzemieńca i innych miasteczek, jak i na prostych, często nie potrafiących się nawet podpisać sędziach ${ }^{56}$. Wyszukane zwroty (np. „stosując się ad mentem ${ }^{57}$ inkwizycyi juramentem zeznanej i naocznie onej dokazywanej”, "na które żadnych dokumentów ani prodokumentów nikt nie komprobuje", ",a tak sąd będąc kommizeracyi jego łaskawym" ${ }^{58}$ ) sporo mówią o mentalności pisarza-szlachcica, który zapewne nie tylko z racji urodzenia uważał się za lepszego od otaczających go mieszczan ${ }^{59}$.

${ }^{56}$ Por. krzemienieckie wyroki podpisywane przez sędziów znakiem krzyża - Krzemieniec, s. 134 (nr 26, 1753 r.), 250 (nr 57, 1764 r.).

${ }^{57}$ W rękopisie: "ad mętem”.

${ }^{58}$ Krzemieniec, s. 53, 54, 57.

${ }^{59}$ Dodajmy, że pan Jan Józef z Rudnickich Tysowski próbował też swych sił jako poeta - na odwrocie karty tytułowej rozpoczętej przez siebie księgi zamieścił bowiem wiersz, w którym, wyrażając również swoje osobiste przekonania, protestował przeciwko złagodzeniu przez sąd wyższej instancji (asesorię?, starostę?) wyroku wydanego przez sąd krzemieniecki w sprawie popełnionego rzekomo pod Zasławiem mordu rytualnego: „Die 22da mais 1747 anno.

$\mathrm{O}$, Sędzio Sprawiedliwy, Tyś Boże Dobrotliwy,

Rozkaż Żydów za krew sądzić,

Nie daj fałszywie w tym błądzić!

Dziś za krew chrześcijańskię Twoję świętę

Za dekretem będą czterech Żydów ścięte.

Bo sędzia fałszywy, a niesprawiedliwy,

Duszy swojej wiecznie zdradliwy.

Bo kto Żydów za to życiem daruje,

Ten sobie piekło wieczne gotuje.

Nawróć go Boże do Krwi Swej Świętej,

Aby i sędzia taki nie był za to ścięty.

Amen, tym pieczętuję i konkluduję,

Jan Tysowski, Bogu duszę gotuję".

W pierwotnym dekrecie skazanych było znacznie więcej, a kwalifikowane kary śmierci nadzwyczaj okrutne - Krzemieniec, s. 26-27 (nr 1); Z. Guldon, J. Wijaczka, Procesy o mordy rytualne $w$ Polsce $w$ XVI-XVIII wieku, Kielce 1995, s. 54-55, tam też w aneksie drukowana wersja wyroku (s. 130-141: Wyrok w sprawie o mord rytualny w karczmie Zachalicha pod Zastawiem w 1747 r.). 


\section{Bibliografia}

\section{Źródła drukowane}

Sachsenspiegel. Landrecht und Lehnrecht, wyd. F. Ebel, Stuttgart 2005.

\section{Opracowania}

Abramski A., Sadownictwo podczas konfederacji w Polsce (1672-1793), Katowice 1986.

Czermak W., Sprawa Lubomirskiego w roku 1664, [w:] tenże, Ostatnie lata Jana Kazimierza, oprac. A. Kersten, Warszawa 1972.

Głąb Z., Zbrodnia i kara - z dziejów przestępczości w małym mieście w XVII wieku (na przykładzie Lutomierska), „Studia z Dziejów Państwa i Prawa Polskiego” 2008, t. XI, cz. I; 2009, t. XII, cz. II.

Guldon Z., Wijaczka J., Procesy o mordy rytualne w Polsce w XVI-XVIII wieku, Kielce 1995.

Kamler M., Zbójnictwo i rozbój w Beskidach od drugiej połowy XVI do pierwszej połowy XVIII wieku, [w:] Społeczeństwo staropolskie. Seria nowa, t. II, Społeczeństwo a przestępczość, Warszawa 2009.

Maisel W., Poznańskie prawo karne do końca XVI wieku, Poznań 1963.

Maisel W., Prawo karne w statutach miast polskich do końca XVIII wieku, CPH, 1974, t. XXVI, z. 2.

Maisel W., Sąownictwo miasta Poznania do końca XVI wieku, Poznań 1961.

Maisel W., Tortury w praktyce sadu kryminalnego miasta Poznania w wieku XVI-XVIII, „Studia i Materiały do Dziejów Wielkopolski i Pomorza” 1979, t. XIII, z. 1.

Meinecke W., Das Strafrecht der Stadt Danzig bis zur Carolina, Marburg 1932.

Meye A., Das Strafrecht der Stadt Danzig von der Carolina bis zur Vereinigung Danzigs mit der Preußischen Monarchie (1532-1793), Danzig 1935.

Mikołajczyk M., Interrogatoria ante publicationem decreti. Uroczyste potwierdzanie zeznań w praktyce sadu miejskiego w Grodzisku Wielkopolskim w I połowie XVIII wieku, [w:] Pro memoria. Księga dla uczczenia pamięci Profesor Krystyny Kamińskiej, red. A. Gaca, Toruń 2013.

Mikołajczyk M., Jak obronić oskarżona o czary. Mowy procesowe z 1655 roku w sprawie Gertrudy Zagrodzkiej, [w:] Z dziejów kultury prawnej. Studia ofiarowane Profesorowi Juliuszowi Bardachowi w dziewięćdziesięciolecie urodzin, Warszawa 2004.

Mikołajczyk M., Nadzór właścicieli wielkopolskiego Grodziska nad miejskim sądownictwem w sprawach kryminalnych w pierwszej połowie XVIII wieku, [w:] Historia testis temporum, lux veritatis, vita memoriae, nuntia vetutatis. Ksiega Jubileuszowa dedykowana Profesorowi Włodzimierzowi Kaczorowskiemu, red. E. Kozerska, M. Maciejewski, P. Stec, Opole 2015.

Mikołajczyk M., Proces kryminalny w miastach Małopolski XVI-XVIII wieku, Katowice 2013.

Mikołajczyk M., Proces kryminalny w Oświęcimiu w I połowie XVIII w. Z badań nad prawem miejskim dawnej Rzeczypospolitej, [w:] Dyplomacja. Polityka. Prawo. Księga pamiatkowa ofiarowana Profesorowi Henrykowi Kocójowi w siedemdziesiąta rocznice urodzin, red. I. Panic, Katowice 2001. 
Mikołajczyk M., Przestępstwo i kara w prawie miast Polski południowej XVI-XVIII wieku, Katowice 1998.

Mikołajczyk M., Sąd z Krzemieńca w wołyńskich miasteczkach. Z badań nad dziejami sadownictwa miejskiego w dawnej Polsce, [w:] Regnare - gubernare-administrare. Prace dedykowane profesorowi Jerzemu Malcowi z okazji 40-lecia pracy naukowej, red. S. Grodziski i A. Dziadzio, t. II, Z dziejów administracji, sądownictwa i nauki prawa, Kraków 2012.

Mikołajczyk M., "Stosujac się do prawa wyraźnego..." Podstawy prawne wyroków kryminalnych grodziskiego sadu miejskiego w latach 1702-1756, „Studia Iuridica Lublinensia" 2013, t. XIX [poświęcony pamięci Profesora Mariana Lecha Klementowskiego (1943-2013), red. M. Kuryłowicz, W. Witkowski].

Mikołajczyk M., Tomasza Piotrowskiego żywot niegodziwy. Przyczynek do dziejów przestępczości w Polsce wieku Oświecenia, „Z Dziejów Prawa” 2009, t. II (X).

Mikołajczyk M., Z dziejów zbrodni i kary w dawnej Polsce. Żywot i proces Antoniego Złotkowskiego, zbójnika z Pcimia, Katowice 2001.

Płaza S., Historia prawa w Polsce na tle porównawczym, cz. I, X-XVIII w., Kraków 1997.

Słownik geograficzny Królestwa Polskiego i innych krajów słowiańskich, Warszawa 1880-1914, t. V.

Sobczak J., Ustrój miasta $i$ organizacja sadownictwa miejskiego Stupcy w XVII i XVIII wieku, [w:] Historia prawa. Historia kultury. Liber memorialis Vitoldo Maisel dedicatus, red. E. Borkowska-Bagieńska, H. Olszewski, Poznań 1994.

Uruszczak W., Tortures judiciaires dans l'ancienne Pologne à la lumière du Livre des malfaiteurs du Tribunal criminel de Wiśnicz du XVIIe siècle, [w:] La torture judiciaire. Approches historiques et juridiques, red. B. Durand, przy współpracy L. Otis-Cour, Lille 2002. 